Article

\title{
Agro-Food Innovation and Sustainability Transition: A Conceptual Synthesis
}

\author{
Xiangping Jia
}

Citation: Jia, X. Agro-Food

Innovation and Sustainability

Transition: A Conceptual Synthesis.

Sustainability 2021, 13, 6897.

https://doi.org/10.3390/su13126897

Academic Editors: József Tóth and Áron Török

Received: 24 May 2021

Accepted: 15 June 2021

Published: 18 June 2021

Publisher's Note: MDPI stays neutral with regard to jurisdictional claims in published maps and institutional affiliations.

Copyright: (c) 2021 by the author Licensee MDPI, Basel, Switzerland. This article is an open access article distributed under the terms and conditions of the Creative Commons Attribution (CC BY) license (https:// creativecommons.org/licenses/by/ $4.0 /)$.
Agricultural Information Institute, Chinese Academy of Agricultural Sciences, Beijing 100081, China; jia.xiangping@outlook.com

\begin{abstract}
The global community faces the challenge of feeding a growing population with declining resources, making transformation to sustainable agriculture and food systems all the more imperative and 'innovation' all the more crucial. In this study, agro-food system innovation (re)defines sustainability transition with a complexity construct of cross-scale interaction and an adaptive cycle of system change. By taking a panarchical view, top-down and bottom-up pathways to innovation can be reconciled and are not contradictory, enabling and constraining innovation at every level. This study breaks down the structure of the agricultural innovation system into four components based on multi-level perspectives of sustainability transition, namely: actors and communities, interaction and intermediaries, coherence and connectedness and regimes rules and landscape. Meanwhile, this research frames the functional construct of system innovation for food and agriculture with five perspectives drawing on broad inputs from different schools of thought, namely: knowledge management, user sophistication, entrepreneurial activities' directionality and reflexive evaluation. This research advocates for an ecosystem approach to agricultural innovation that gives full play to niche-regime interactions using social-technical perspectives.
\end{abstract}

Keywords: agricultural innovation systems; pathways; food systems; entrepreneurship; niche; agroecology

\section{Introduction}

The global community faces great pressure to feed a growing population. By the end of the 21st century, the world population is projected to reach 11 billion. As the population grows, so will the associated challenges, such as inequality, environmental degradation, disease, social conflicts and hunger [1]. Globally, one in three people were malnourished in 2018 and, if the current trend continues, one in two people could be malnourished by 2030 [2]. Despite the rising urgency to address global hunger, growth in agricultural productivity has halted since the start of the 21st century, partly due to dampened investment in agriculture and development. Sustainability scholars have called the dominant model of agricultural development that has been in use since the 1960s the 'productivist' model-a system failure for intensifying input use and promoting excessive dependence on trade [3]. To move away from the 'productivist model' towards a more sustainable system that can guarantee global food security in the context of climate change, greater investment is needed. The United Nations Food and Agriculture Organization (FAO), International Fund for Agricultural Development (IFAD) and Women's Empowerment Principles (WEPS) estimate there is an average investment gap of 1.4 trillion USD annually [1].

The ability to transition from the 'productivist' model to a new system is constrained by 'lock in' in a social context. 'Transitioning' to sustainability is still an emerging research field. For a long time, agricultural innovations were viewed as applications of scientific research and knowledge to be achieved by educators disseminating knowledge to farmers. The belief in this knowledge hierarchy shaped agricultural development programs and agricultural policies in developing countries [4,5]. However, the success of the agricultural extension model is contingent on having a homogenous production environment, large 
commercial farm units and stable economic conditions. These conditions are increasingly difficult to guarantee because modern agriculture is no longer used just for production, but also for consumption and environmental purposes. Modern agriculture is also increasingly dependent on external actors like agribusiness firms, finance providers and agencies [6]. Food and agriculture systems therefore cannot be reconfigured by controlling processes, planning, standardization, constancy and predictability. They are dynamic, adaptive, uncertain and complex and require socio-technical interaction and cross-sectorial applications, which is now known as an approach termed agro-food system innovation towards agroecological transitions [7-10]. Research has been conducted on similar transition 'lock-in' in other sectors such as energy, the environment and social media, leading to the development of another emerging term called sustainability transition [11-14]. The analysis in this article combines the emerging concepts of 'agro-food system innovation' and 'sustainability transition', which are similar in meaning but vary in application.

Research and policy institutions continue to characterize agro-food system innovation and sustainability transition as structured and controllable, despite the emerging recognition that they should be flexible and dynamic. While a number of scholars conceptualize them using prescriptive [15] or ontological perspectives [16], others argue that a normative construct is needed to take into account and highlight social needs and responsibility [17]. While the concepts are emerging in the research community, they have not been recognized or used to study agro-food systems and alternatives [18]. At the policy level, policymakers have not yet formulated effective policies to put them into practice [19]. In practice, alternative agrifood initiatives are dismissed as local struggles in the niche and failed attempts at scaling up that have not managed to achieve regime influence or a real 'transition' [20].

This research aims to join the emerging global debate on this topic and fill the knowledge gap. In Section 2, it firstly reviews the evolving framings of sustainability transition from which agro-innovation well represents solutions to the manifested problems, such as food crises, malnutrition, environmental and resource degradation, and associated societal turmoil. In Section 3, agro-food innovation is conceptualized as social-technical complexity of system attributes; panarchical views on agro-food innovation and sustainability transition reconcile opposing ideas about top-down and bottom-up pathways. In Sections 4 and 5, agro-food innovation and sustainability transition are constructed through structural and functional perspectives, as a multi-level interactive system and co-learning processes.

The research has applied value and offers concrete recommendations for policy formulation, normative constructions of agricultural innovation systems (AIS), and analytic tools for capacity building and assessment. Examples of potential applications of this study include the Tropical Agriculture Platform, a G20 initiative to strengthen national innovation systems in developing countries, and the pilot programs of agricultural innovation system (AIS) at the national and territorial levels [21].

\section{Evolving Framings of Innovation and System Perspectives}

There are two established and dominant frameworks that coexist in contemporary innovation literature. The first framework assumes that knowledge derived from science and technology is the driving force of economic growth and innovation [22]. It dates back to the post-Second World War period when policymakers advocated for public investment in research and development (R\&D) and the sponsorship of mission-oriented research to address market failure. This resulted in large-scale, government-funded scientific projects. The science-lead regime caused a divide between developed and developing countries as the latter were disadvantaged by their lack of capability, infrastructure and enabling context [23]. The disparity led scholars and policymakers to reflect, and in the 1980s the second innovation framework emerged. The second framework emphasizes the building of competitiveness and capacity and is shaped by the concept of a national innovation system for knowledge creation and commercialization [24,25]. It focuses on enabling entrepreneurship and knowledge sharing, encouraging business incubators and 
accelerators, clusters and networks. However, the academic community has not reached a consensus on what interventions that should be made under the second framework, meaning that policies and results have been mixed globally.

The two frameworks vary in their conceptualization of innovation and their contribution to development. The model of innovation in the first framework is a linear knowledge transfer process. It presumes that a wide range of stakeholders can coordinate and achieve coherence despite their different objectives and responsibilities [26,27]. The model expects the science-led process will contribute substantially to long-term economic growth and provide numerous business opportunities. The model of innovation in the second framework takes a more functional view and considers the effect of the social-historical context on innovation. Instead of viewing the innovation system as consisting of multiple stakeholders, the second framework places user-entrepreneur relationships at the heart of the system. The roles of other agencies are recognized but limited to facilitating the dissemination of information and knowledge to support entrepreneurial decision-making [28]. Instead of conceptualizing innovation as a linear flow from science to applied R\&D and to commercialization, the model in the second framework focuses on the interactive nature of innovation across different networks. The second framework assumes that knowledge is tacit and built up cumulatively [29].

The framing of innovation has been further developed by integrating the concept of sustainability transition. The science-led innovation regime under the first framework is top-down and technocratic. It does not integrate broader societal issues into interventions. The second framework, as described by Schot and Steinmueller [30] (p. 1561), is one that "explicitly introduces participatory and inclusive processes that are empowered to identify alternatives and to influence or take decisions regarding all possible options. This is not a process which should be left entirely to the scientific community". Both of the existing frameworks have been overly optimistic about the benefit of innovation to social welfare as more and more countries and individuals have been left behind in terms of development. The third, alternative framing of innovation, which integrates the idea of sustainability transition, focuses on directionality (what future do we want?), legitimacy (why do we want this future? Who defines it and why them?) and responsibility (transformation by and for whom?) [17]. This third framework does not offer a model of best practices and regulations but "focuses on innovation as search process on the system level, guided by social and environmental objectives, informed by experience and the learning that accompanies that experience, and a willingness to revisit existing arrangements to de-routinize them in order to address societal challenges." according to Schot and Steinmueller [30] (p. 1563).

Agro-food system innovations are socio-technical changes that occur in response to a number of persistent problems confronting contemporary food and agricultural systems. These manifested problems, such as food crises, malnutrition, environmental and resource degradation, are persistent, non-cyclical and worsen as time progresses; some of them lead to profound societal turmoil and tension [1]. Yet the search for sustainability has been locked in by existing socio-economic-technical regimes that advocate for stability. System innovation and sustainability transition necessitate a different approach that creates shifts across regimes on a large scale [12].

\section{Innovation as Complexity Constructs of System Change}

\subsection{The Social-Technical Construct of Complexity}

Food and agriculture are often conceptualized as complex systems. However, as a conceptual term, complexity is often used to describe situations rhetorically without being clearly differentiated from those which are simple or complicated. A simple situation is one where there is a widespread agreement about what to do and it is possible for top-down intervention to involve detailed planning and controlled execution [31]. In complicated situations, the desired outcomes are less predictable and certain but what needs to be done can be identified and achieved with technological breakthroughs and social communication. However, in complex situations the outcomes of interventions aimed at solving problems 
are unpredictable and uncontrollable. A large number of factors and variables interact with one each other and many are unknown and even "unknowable", given the limited number of tools and approaches available [32] (pp. 137-139). The core distinction between complicated and complex situations is the extent to which there is (or can be) causality. A system (such as farming) involving different stakeholders (or actors) who articulate competing values and propose conflicting solutions is a complex issue rather than a complicated one.

It is useful and important to distinguish social and technical complications for innovation. Michael Quinn Patton [33] developed a matrix that makes this distinction by mapping situations along two dimensions. One dimension scales the degree of certainty about what should be done to solve a problem. The author defines this as the technical implications. The second dimension depicts the degree of agreement (or conflict) among various stakeholders about an intervention. This dimension is characterized as social complications. Combining these two dimensions creates a matrix where the horizontal axis captures the degree of certainty about how to solve a problem and the vertical axis displays the degree of agreement about what to do.

In socially complicated situations (such as farming systems or anti-poverty programs), it is not just the fact that people disagree that matters, but the depth and source of disagreements [34]. What makes agricultural innovation especially complex (instead of complicated) and challenging is that those involved have fundamentally different perspectives and values or operate on different paradigms about how the world works and what is important [35]. Their differences are constantly evolving and intertwined with communities of great diversity.

\subsection{An Adaptive Cycle of Innovation and System Changes}

While complexity has been considered by some as a source of uncertainty, an alternative view suggests the complexity of living systems emerges from a small number of controlling processes. Drawing from an example from agro-forestry ecology, Gunderson and Holling [36] propose a framework to understand the complexity of economic, ecological and social systems. In a complex system, transformations at the system level are developed through four phases that make up a recurring adaptive cycle: release, reorganization, exploitation and conservation. The adaptive cycle takes the form of an infinity loop mapped along a two-dimensional matrix (Figure 1). The horizontal dimension measures the diversity of the system along a "connectedness" continuum that measures variability (such as biodiversity in ecological systems or heterogeneity in social systems); it reflects the conformity or controllability of a system. The vertical dimension measures the extent to which the inherent potential and resources in a system are released or stored. In a socialeconomic system, the accumulated potential for value creation is derived from capital, skills, networks of human relationships, and mutual trust that are developed incrementally.

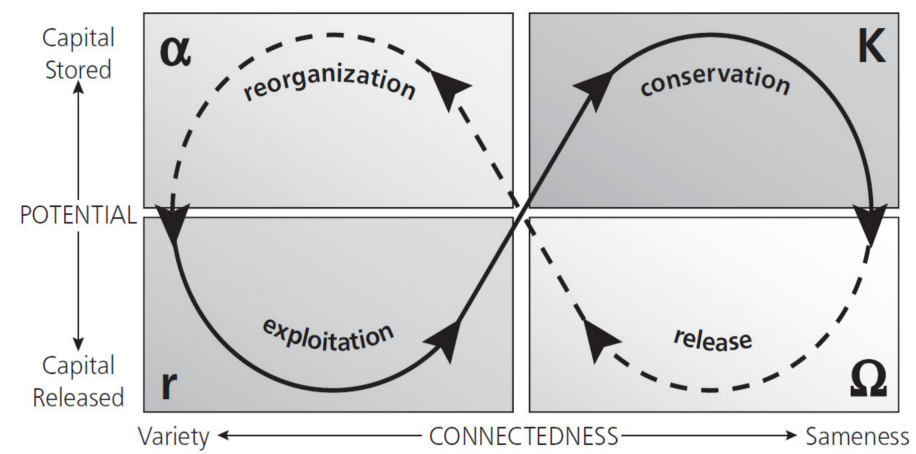

Figure 1. Adaptive cycle of complex economic, ecological and social systems. Source: Reused with permission from reference [37], copyright (2021) by Springer Nature and Copyright Clearance Center. 
The different possible combinations in the four quadrants are the system dynamics. The upper-right quadrant $(\mathrm{K}$, for kappa) represents the conservation phase of a mature system, such as a stable ecosystem with relatively low biodiversity where the system's resources are mostly taken up by the dominating species. Social and economic K-types are incumbents like large transnational companies (TNCs) or public entities (such as stateowned companies or public institutions). In a regime at this phase, the ruling variables are forced standardization, emphasis on accountability, bureaucracy, rigidity and resistance to necessary change. The lower-right quadrant $(\Omega$, for omega) represents the release phase when resources that have been locked up in the mainstream are set loose, as occurs when a fire ravages a forest, a large business fails or a financial crisis occurs. This phase was coined for use in social-economic systems by economist Alfred Schumpeter in the 1940s when he studied economic cycles and argued for the importance of and rationale for "creative destruction" to topple the old regime (that is dominated by K) and unleash innovation and creativity.

The upper-left quadrant ( $\alpha$, for alpha) depicts a niche that departs from the mainstream and explores reorganizations. In an ecosystem that suffered a crisis (such as fire in a forest), a large number of new plants or animals start to emerge and compete for resources. In a post-crisis economy, these are entrepreneurial start-ups (or similar social organizations) that experiment with innovations. For an economic or social system, skills, networks of human relationships, and mutual trust accumulate and reorganize during the progression from $\Omega$ to $\alpha$. In a social-economic system, the transition phase from $\Omega$ to $\alpha$ is characterized by scarce resources, downsizing organizations, high stress, and identity confusion in both individuals and groups. It is a time of disparate experimentation and much failure, but a small number of successes start to emerge and attract resources.

The lower-left quadrant $(r)$ is the exploitation phase when resources are being released for new growth. The transition from $\alpha$ to $r$ is a converging process when resources are directed to the most promising possibilities. The frontrunners grow into dominance and the cycle returns to where the system began - the conservation regime. Resources are locked up and elements have a low innovative capability.

At the heart of debates about the complexity construct of transformative innovation is the direction of innovation. Both of the above theories on system change for sustainability oppose marginal and incremental changes. Transformation is differentiated from mere "improvements" or "adjustments". Rather, it is described as a dramatic and top-down regime shift [38]. Such an approach to transition management has been criticized, however, for democratic disconnect and overstating the role of elites and leadership [39]. Nevertheless, alternative views about sustainability transition have been also criticized for not defining clear pathways between the different levels and a bias towards bottom-up change [40], neglecting the potential of broader secular changes that create favorable conditions for revolutionary uprisings and create 'structural opportunities' [41].

The idea that sustainability transition can be facilitated and constrained by both topdown and bottom-up pathways is defined as "Panarchy" — an image borrowed from the Greek god Pan-who was the epitome of unpredictable change-to depict the evolving nature of complex systems [36]. In a panarchical construct of transformative innovation, dual top-down and bottom-up pathways are depicted as an adaptive cross-scale interaction that combines experiments and learning with continuity. Both of the pathways can trap system change into situations that are hard to adapt. On the one hand, the top-down pathway may have abundant resources and high connectivity, but it is trapped in rigidity. On the other hand, the bottom-up pathway is impoverished and innovation is trapped by poverty, even when it survives in the niche. Panarchical views on sustainability transition and transformative changes reconcile opposing ideas about top-down and bottom-up pathways, and assert that both of them can be innovative and conservative. Transformative changes of panarchy views are portrayed using the framework of strategic niche management for sustainability and innovation [42-44]. 


\subsection{System and Complexity Inquiry of Agro-Food Innovation: Where Next?}

The concepts of innovation and sustainability transition can be used to address a set of questions that dominant approaches to agricultural research are poorly equipped to address. Conventional approaches to studying food and agriculture are usually specialized into different disciplines (such as commodities or sectors): productivist that seeks continuous productivity gains, homogeneous and controlling of the production environment and context $[4,45]$. As farming systems become increasingly diverse, agricultural technologies increasingly need to take the environment and social context into consideration [46]. Several analytical approaches based on different theories and epistemology define innovations in food and agriculture as a knowledge infrastructure that interprets national or sectoral innovation systems $[47,48]$ as socio-technical systems consisting of multiple actors and relations [49,50], a set of functions [51-54], a dynamic process of multi-actor interaction and learning [55-57] and a system to navigate complexity, collaborate, reflect and learn to engage in processes [58]. How do these views contribute to the framing of agro-food system innovation and sustainability transition?

\section{The Structural Construct of Agro-Food Innovation and Sustainability Transition as a Multi-Level Interactive System}

Structuration theory views that actors are embedded in structures (i.e., resources and rules) and draw upon structures using concrete actions and local practices [59]. Therefore, structures are both mediums and outcomes of actions. According to structural views of innovation systems, actors are not passive rule-followers but knowledgeable agents who use the rules to interpret and (inter)act through reflexive learning. Similar to neoinstitutional sociology, structuration theory distinguishes three kinds of rules/institutions: regulative, normative/interpretive and cognitive [60]; the rules influence actions through different mechanisms. Rules do not exist individually, but are linked in semi-coherent sets, forming multiple regimes in areas such as economics, politics, law and culture [61,62].

Nonetheless, systems are different from structures and the distinction is important for sustainability transition. Structures are the rules and resources that actors draw upon recursively while acting according to concrete local practices [12]. Systems refer to mutual dependencies and interactions between actors, such as exchanges, conflicts, coalitions, negotiations and strategy games. Systems have structural properties, but they are not structures themselves (op cit.). To study the structuration of a system, such as food and agriculture, it is important to "study the ways in which that system, via the application of generative rules and resources, and in the context of unintended outcomes, is produced and reproduced in interaction" [59] (pp. 65-66). In other words, structuration approaches focus on resources and rules that actors draw upon, but system approaches focus on the (inter)actions of actors. Importantly, the system view of innovation acknowledges the role of material and technical elements and therefore frames innovation using sociotechnical perspectives [12].

The construct of sustainability transitions as systems was conceptualized using multilevel perspectives (MLPs). According to MLPs, system innovations for transformative change result from the interplay of developments at three analytical levels: niches (the locus for radical innovations), socio-technical regimes (the locus of established practices and associated rules that stabilize existing systems) and an exogenous socio-technical landscape $[12,13,63]$. The socio-technical landscape forms an external context that actors at niche and regime levels cannot influence in the short run. Regimes provide stability in the system but also cause lock-in and hamper innovations. Working on radical innovations that deviate from existing regimes, niche actors (such as entrepreneurs, start-ups, spinoffs) articulate expectations and enroll new actors into the system outside the existing regimes.

Regime change is a nexus of several subsystems and it is the principal locus for transition. According to MLPs, a regime may consist of several sub-regimes or subsystems that interpenetrate and co-evolve with each other [12]. The notion of a socio-technical regime not only clarifies interactions across different levels and the pathways, but also 
aims to capture the meta-coordination between different sub-regimes, and therefore goes beyond sectorial systems [62]. According to extant literature about agricultural innovation systems [58,64,65], agro-food regime has eight sub-regimes or subsystems, namely: production, users and markets, supply, R\&D, finance, public authorities, civil society and intermediaries (Figure 2).

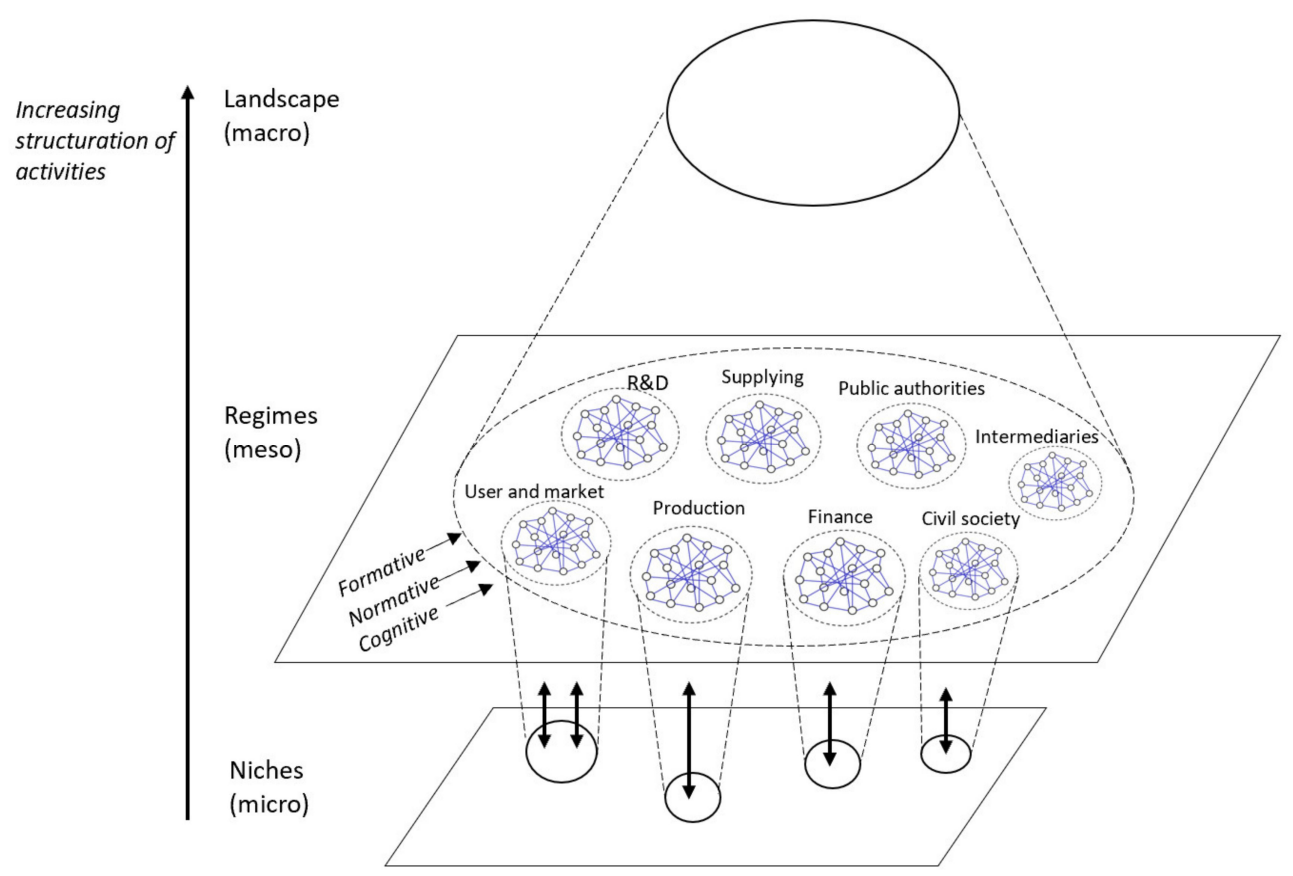

Figure 2. Structural construct of agro-food innovation through multi-level perspectives.

Niche-regime interactions are crucial for framing agro-food innovation and sustainability transition. While both niches and regimes provide structure to actions in local practices, the degree of structuration varies in size, stability and complexity [12]. When it comes to niche-innovations, networks are unstable and loose, with actors entering and exiting frequently; rules are vague, imprecise and sometimes conflicting, be them regulatory, normative or cognitive. Working on path-breaking innovations that deviate from existing regimes, niche actors (such as entrepreneurs, start-ups, spinoffs) articulate expectations and enroll new actors into the system from outside the existing regimes. Regime rules are well-articulated and relatively stable, and thus provide stronger structuration and have a greater constraining influence. Regimes provide stability in the system but also cause lock-in and hamper innovations, given that there are dominant practices guiding rules and decision-making. Nonetheless, regime change does not come about by bottom-up processes only and is the sum of niche development [66]. Some other MLPs on the dynamics of transition assert that niches may also emerge within a regime and not necessarily at the micro level [67]. Niche development, maintained through local initiatives, requires outward orientation, 'anchoring', and focus on the changing interdependency of the niche and the wider social world [68]. The interaction between niches and regimes is displayed as two-way arrows in Figure 2.

\subsection{Actors and Communities}

Agro-food systems are characterized by multi-actor structures. It has been widely agreed that agricultural innovations are multi-actor and multi-facetted processes involving a wide range of stakeholders, such as consumers, farmers, firms, universities and knowledge institutes and public authorities [49,64,69]. Depending on the underlying assumptions, these actors are conceptualized and framed as autonomous agents [70], hybrid and network-like organizations between hierarchy and the market [71,72] or intermediated 
through innovation brokers [73]. Despite the consensus that there are multiple actors, the discourse about them has become rhetorical. The development of multi-actor structures into 'partnerships' is widely advocated but confused in practices [74].

The structural construct of system innovation with regards to food and agriculture is constituted of individual actors and dedicated communities that permit individual knowledge to be combined with shared views and collective action, to the extent that the interests and activities of individual actors are aligned. Dedicated communities vary greatly, ranging from loosely organized farmer groups that are driven by economic benefits ('functional-

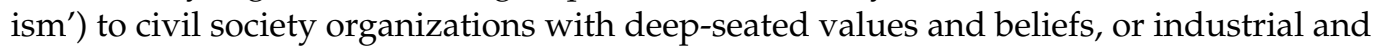
academic consortia with organizational charts ('structuralism' and 'relationalism') [16]. Communities and federations are important for autonomous decisions and interaction processes in which information and resources are exchanged. While most agro-food communities are bounded in locale [75,76], digitalization transforms geographic borders and facilitates 'socialized' communities [77], such as various alternative food networks and supportive community agriculture [2]. The constituents of communities (as actors) in the system introduce not only global-actors but also 'meso-rules' because these community actors stipulate intra-rules and sometime influence the (regime) rules through direct action or through facilitating communications (such as social media, conferences and journals). They actively use, interpret and implement the rules but also control and reform the rules, forming a "social rule system" [78].

The epistemology of various approaches to framing multi-actors in agro-food systems is fundamentally different. In neo-classical economics or realist approaches, actors (such as farmers or consumers) are represented as having a fixed set of preferences as part of (quasi-)rational agency and having some kind of formula in their mind to make optimal adoption choices [79]. The process of innovation is perceived as "alertness and discovery" of opportunities by agents with particular subjective localized knowledge [80]. Different from the opportunity-alertness perspectives, another strand of thinking views innovation as individual phenomena. In this constructionist view on innovations, 'opportunities' are formed by Schumpterian entrepreneurs or individuals who have unlimited resources and freedom and then mold their actions to realities [81,82]. Building on the strengths and limitations of both realist and constructionist approaches, the evolutionary and socio-technical approach agrees that knowledge and 'reality' is constructed by individuals but validated through socio cross-validation, blind-variation and the selection-retention process; trials and errors are unavoidable and necessitate social interactions [83,84]. According to this third approach, actors are embedded in wider structures, which configure their preferences, aims, strategies and capabilities.

The analytical approaches to actors and communities in various perspectives is central to frame agro-food innovation. Geels suggests to making an analytical distinction between systems and the actors involved in them [62]. Such a distinction is greatly useful because a large number of heterogeneous actors in agro-food systems confound the boundaries, leading to the descriptive feature called "pluralism" [50,85]. To frame agro-food innovation for sustainability transition, the analysis should go beyond sectorial perspectives, focusing on interactions of actors within and across (sub-)regimes [7]. Such interactions in system innovations are open-ended and co-evolving processes of individual actions (in the private sphere), organizational/community practices of shared rules (in the collective sphere) and unintended influence (in the public sphere).

\subsection{Interaction and Intermediary}

Rather than mapping actors by delineating identities, transformative innovations and sustainability transition are characterized by interactions among actors [86]. Unlike interactions within the levels (or subsystems) that maintain adaptive opportunities, interactions across levels (between technology, policy, economic and public discourse) hold the structure together and promote system innovations [28,36]. For example, the process of 
niche-regime interactions enrolls new actors and constructs shared visions of associated agrifood network actors, which eventually leads to the reconfiguration of the regime [87].

Intermediary bodies have been widely recognized as important system constituents to facilitate interactions, but the conceptual views of the roles of intermediary bodies are not well aligned with real-life practice. A general definition of their role is to facilitate, mediate and advocate [88]. Some narrowly define intermediaries as "agricultural extensions" between agronomy-science and farming practices in a top-down knowledge management regime. However, the idea of extension agencies does not take into account intermediaries' interaction with and social learning from a wider range of actors (such as users and civil society) [54,89]. Another school of thought views intermediaries in innovations as participatory processes that "support the work of different types of teams in solving mostly complex problems and in developing decision solutions" [90] p. 139, and facilitate group formation and communicating dialogue [73,91]. Embedding intermediaries in agro-food innovations using system perspectives remains challenging and outside the mainstream body of thinking; many assume the legal identity of non-governmental organizations (NGOs) instead of having their own independent professionalism [74].

Only recently were the presence and function of intermediaries in agricultural innovation systems framed in sustainability transition. Panarchical systems of food and agriculture do not see top-down and bottom-up innovation as contradictory. Rather, they allow for interactions and coordination between different actors involved in transformative innovations to achieve learning and practices at different levels [87,92,93]. For example, some intermediaries help articulate government policies and 'vision' and transfer them from the landscape and regime levels to local practices. Once verified, niche innovations and experiments need facilitation to interact with other actors in the regime in order to scale up. Intermediaries act as 'innovation brokers' to build linkages and facilitate interactions $[73,74]$.

\subsection{Coherence and Connectedness}

Coherence and connectedness are determinants of the stability and rigidity of regimes. Coherence indicates diversity, shared rules and alignment among (sub-)regimes [36]. Connectedness measures the internal controllability of the regime by its own density and reflects the degree of flexibility or rigidity of established rules and controls within a regime (op. cit.). When a regime exhibits a high degree of stability and rigidity, it becomes hard for innovation to emerge within the regime, and a new socio-technical configuration outside the regime (such as in niches) faces resistance and lock-in. Transition is prevented by rigidity.

The coherence and connectedness of each regime depends on its adaptive capacity (or resilience). The adaptive capacity of a regime is in turn related to its ability to recognize its vulnerability to competitive threats from other regime members and reorganize improvements in the face of the competitive selection pressures [94] (p. 64). Coherence and connectedness can be formed and enforced through political or market powers and the formation of social order with 'guiding visions' [95]. However, 'societal consensus' or 'public interest' which are formed in this way are not very adaptive as they are formulated with few interactions within and across the regimes.

\subsection{Regime Rules and Landscape}

Building on the institutional theory and sociology of technology, 'regime rules' distinguish different kinds of rules (regulative/normative/cognitive) that affect human action in agricultural innovation systems [60]. Regulative rules refer to explicit and formal specifications, such as legislation, regulations and standards. Normative rules are social norms, values, role expectations, duties and responsibilities; these are internalized through socialization processes. Cognitive rules are the nature of reality and frames through which meaning or sense is made or symbolized, such as habits, user preferences, metaphors or beliefs. The rules are linked and are not single autonomous entities, and the alignment of 
the different sets of rules deliver regime stability. It is difficult to change one rule (such as property rights), without altering others (such as labor mobility and migration regulations). In socio-technical regimes, rules are not just linked within regimes but also across a variety of sub-systems (like science, technology, policy, users and market, and culture), playing a meta-coordinating role [62].

The metaphor of a 'landscape' is used because of the connotation of relative stability. 'Landscape' connotes the 'hard' infrastructure and spatial arrangements that constitute it, such as electricity, infrastructure and urban planning. It defines trans-regime rules (regulative, normative and cognitive) that underlie the foundation of the structure of systems, such as pressure, politics, power dynamics, perceptions and purpose [96]. A landscape provides a stronger structuration of activities than regimes; it does not necessarily have more direct effects on actors than regimes but it channels transition processes and undergoes shifts slowly in an autonomous way [62,97]. A landscape provides "deep-structural gradients of force that make some actions easier than others" here or difficult elsewhere [12] p. 29. The socio-technical landscape of sustainability transition differs from conventional contextual constructs because it includes misalignment and shocks, such as crises and climate change. External disturbances may create pressure on societal groups and regimes and affect people's perceptions.

Understanding the analogy and distinction between the landscape and the 'enabling environment' is crucial for framing agro-food innovation for a sustainability transition on a societal scale. Neither the landscape nor the enabling environment can be influenced by niche or regime actors in the particular domain they are in in the short run. However, while the enabling environment is relatively static, the landscape is influenced by changes in the external environment and interactions made by human agency, making it more dynamic [12].

The mainstream discourse about enabling environment dismisses the distinction between landscape and regime rules, and conceptualizes the external environment as part of the regime in a 'top-down' approach. The landscape cannot be affected, meaning the pre-defined goals of regime actors and the external environment are not sufficient to enable a transition until a bottom-up response facilitates niche-to-regime processes [97]. In the structural construct of the landscape-regime, the regime actors are engaged with and adapt to the external environment, especially when operating under conditions of resource-constraints and market failure.

The role of landscape in the structural constructs of agro-food innovation implies a bricolage approach of mobilizing resources to achieve transformative innovations. Given that niche innovations mostly operate under conditions of resource-constraints in sectors with few economic opportunities or even market failures, the role of resources is often called into question [82]. While resources enable innovations, they are often locked in existing regimes and the landscape. Bricolage, the process of mobilizing resources at hand-be they material, labor and/or skills, allows social entrepreneurs to "make-do" and overcome project input constraints [98]. A fundamental aspect of bricolage involves the adaptive combination and, potentially, recombination of resources to solve problems, rather than awaiting for enabling resources to become available [99,100]. This "trove" of resources allows entrepreneurs to find creative solutions to social problems and act as a medium of social change. According to the bricolage approach, innovations do not result from the 'enabling environment' but rather 'enable' the environment through cognitive learning and adaptive practices.

\section{The Functional Constructs of Agro-Food Innovation and Sustainability Transition as Co-Evolved Learning}

The other strand of literature frames agricultural innovation systems using functional perspectives. Unlike structuration approaches, which focus on actors, resources and rules, functional perspectives emphasize how (technological) innovation systems work. The first school of innovation theory that used functional approaches decomposed and determined the overall system of function by several sub-functions: the generation, diffusion and use of 
innovations [51-53]. Scholars of this group later developed specific mapping tools to evaluate the internal strengths and weaknesses of these functions and specific socio-technical trajectories [101,102]. According to functional perspectives, a well-functioning innovation system is characterized by (a) entrepreneurial activities, (b) knowledge development, (c) knowledge diffusion in networks, (d) guided search, (e) market formation, (f) resource mobilization and (g) creation of legitimacy/overcoming resistance to change [51] (p. 418). After an extensive review of literature that discusses 'functions' of technological innovation systems, Jacobbson and Johnson [103] identified five functions performed by innovation systems, including (a) creation of new knowledge, (b) search processes among users and suppliers (of technology), (c) supply of resources, (d) creation of positive external economies and (e) market formation.

The functionalist views of agro-food innovation have been questioned in many respects, from ethics to methodology. It is widely recognized today that innovation goes beyond its contribution to economic growth and requires more than technological innovation. It delivers higher quality outcomes, i.e., functional changes in eco-efficiency, a combination of technological, organizational and institutional innovation, the involvement of multiple actors, new guiding principles and sets of goals, and long-term changes at the micro- and meso-levels [38]. Functional analyses of innovation systems tend to abstract functionality from the totality of the structure. Those that oppose the functionalist approach propose a long-term perspective and shift in regimes/paradigms, rather than pursuing the functions in the short run, in order to take into account the complex nature of system innovation in sustainability transition (which is defined by nonlinearity, emergence and uncertainty) $[104,105]$.

Notwithstanding criticism, functional perspectives appeal to a broad range of institutions, such as financial institutions, and public administration and development agencies, given the mandates they have to carry out performance evaluations. Patton [33] argues that, to posit the macro functionality of innovation, micro and static studies are still needed to validate the value propositions of innovation [33]. In the real world where institutions have limited tenures and are subject to contractual responsibilities (such as is the case for development agencies), tools are needed to evaluate the accountability of interventions. This is expected to inform policy by identifying the 'motors of innovation' that accelerate development and the constraining factors that hinder innovation [106]. Outcome-based approaches remain practically useful but have not been fully aligned with the sustainable development goals (SDGs) of the United Nations [107].

This study proposes an analytical framework to clarify the role that functional analysis can play in helping agricultural innovation systems transition towards sustainability. The functional constructs of agro-food innovation and sustainability transition are identified using five constituents (Figure 3), namely knowledge generation and access, user sophistication, entrepreneurial activities, directionality and reflexive evaluation. 


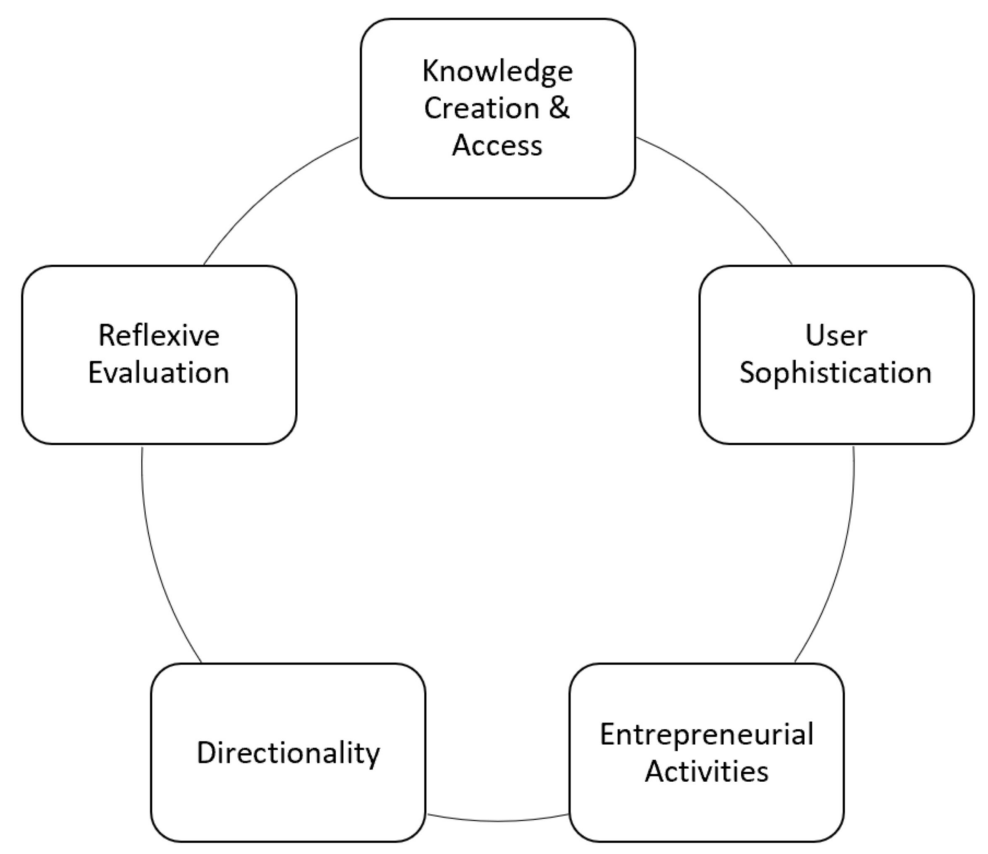

Figure 3. Functional construct of agro-food innovation and sustainability transition as a transformative process.

\subsection{Knowledge Management}

Knowledge and innovation management distinguish two types of knowledge, explicit and tacit. Explicit or codified knowledge can be articulated, codified, stored and transmitted to others without changing the content and format of the knowledge. The most common forms of explicit knowledge are manuals, documents, programs and databases. Explicit knowledge is often confused with information given neither of them rely on knowledge derived from experience. Management science disregards the importance of explicit knowledge relative to tacit knowledge [108]. Tacit knowledge refers to knowledge that is largely based on practice and is deeply rooted in action, commitment and involvement [109]. As a result, tacit knowledge is often contextual and personal in nature. Tacit knowledge is sometimes referred to as know-how and has been considered essential for innovation and sustained competitiveness [110].

Agriculture as a knowledge system is dominated by tacit knowledge that is deeply rooted and embedded in social structures (e.g., farmers, informal groups, communes), posing a great challenge when it comes to interacting with the codified knowledge of scientific disciplines. Tacit knowledge includes skills, capability and expertise, as well as values, belief and attitudes. As a consequence, knowledge creation in agriculture innovation systems is embedded in society and locked into processes and social structures, such as routines and culture [110]. As agro-food innovation requires multi-level actors and institutions, networking and interaction determine innovation capacity [111]. For tacit knowledge management, it is essential to strengthen organizational learning capacity that fosters self-organizing flexibility, trials to reduce uncertainty and effective feedback loops [112].

Access to knowledge for all depends on a vast network of regime actors (i.e., research institutes, intellectual property rights regulatory bodies, the private sector and civil society) and policy coherence. Agricultural intellectual property includes that of both private toll goods (non-rival) and public goods (non-rival and non-exclusive). When protected by intellectual property rights (IPR), knowledge becomes a toll good that is accessible only when created for the first time or purchased. This has profound implications for the cost structure of the research industry that is biased towards large-scale organizations (e.g., incumbents, research institutes and universities) and countries [113]. The persistence of global inequality underscores the need to transmit knowledge across borders and continents to build capacity in less developed areas [106]. However, at the global and 
national level, access to knowledge and R\&D capacity still faces challenges when trying to align with different IPR regimes and development goals [5]. A key issue, as asserted by the OECD, is the protection of IPR and the difficulty in defining the scope and duration of IPR to provide enough incentive for private investment in agricultural knowledge and research, without compromising the societal benefits of sharing the knowledge and stimulating innovation.

Given that market failure results from research spillovers and the non-rival nature of knowledge, innovative public-private partnerships in knowledge management are crucial for agro-food innovation towards sustainability transition. Public and levy funded research organizations can play an important role in creating efficient agricultural knowledge systems and ensuring their accessibility to society. Industry-oriented research has an advantage over public-funded research as it focuses on downstream knowledge users. Cooperative mechanisms and synergy effects create incentives and returns on investment by taking advantage of the private sector's technical expertise, and the public sector's ability to direct societal needs [114]. Notwithstanding a handful of successful cases, a great deal remains to be learned about the operation and practice of aligning agricultural knowledge and sustainability goals [5].

\subsection{User Sophistication}

User sophistication distinguishes agro-food innovation from sectorial innovation in specific fields or technologies. The early school of thought conceptualized sectorial innovation as a 'triple helix dynamic' that firms, public authorities and universities work on together $[115,116]$. Such an approach mainly looks at the supply-side and the production of innovations, taking the user sider for granted or simplifying it to 'the market' which functions as a natural section environment. However, agro-food system innovations are not only influenced by the supply-side, but also by users and unintended groups who are embedded in the application domains. Users do more than just buy or adopt (new) technologies but act as 'agents' to 'domesticate' the use of new products/services and technologies to fit existing user contexts [117-119]. The domestication fits in the functional domain of innovations and involves symbolic and cognitive process (individual nexus), group learning and behaviors (community nexus) and embedded culture (societal nexus) [120]. User sophistication implies that system innovations not only involve changes in technical knowledge and industries, but also changes in user contexts and symbolic meanings.

User sophistication recognizes the fundamental role of human agency in agro-food innovations and advocates for socio-technical interactions towards sustainability transition. Technological innovation refers to realizing functionalities in concrete user contexts, which are made up of users, their competencies, preferences, routines, cultural values and interpretations [117]. As users interact with new technologies (and possibly undergo change accordingly), they build up experience and gradually explore new functionalities through 'probing and learning'; they develop new cognitions and concepts with which to make sense of the technologies [121]. User sophistication makes entrepreneurs aware of the context of regime and landscape because the contexts are shaped by a variety of existing artefacts and infrastructures (such as transportation, information and communication technologies, and electricity networks) and regulations. From an evolutionary perspective, end-user influences are more systemic and preferences and practices can reshape the socio-technical configurations of regimes (e.g., regulations, standardization, policies) and the landscape (e.g., infrastructure, cognitive perception and culture) [117].

User sophistication is essential for change to happen in a complex system. With the emergence of modern technologies (such as smart technologies), it is easier for discrete and niche innovations to come to market. Nonetheless, in socio-technical systems that are nonlinear and have dynamic complexity, there are both intended and unintended consequences of the processes in such systems. Stroh [122] positions unintended consequences at the heart of systems thinking for social change. Surfacing unintended consequences differentiates 
the short- and long-term logic model of social change, and gleans insight into the "emergent properties" of innovation, as seemingly unintended outcomes and users at a lower scale might emerge higher up on the scale [12] (p.142). However, it is often easy to over-simplify by not looking beyond the "theory for unintended" outcomes, which prevents other explanations from being identified [123]. Attempts to create new models of agriculture often fail because they do not fully understand the informal systems that they were about to replace or transform [124].

User sophistication is different from market sophistication. Market sophisticationdescribed as a set of events and activities that constitute marketplace and functions, including demand articulation, searching, matching, exchanging, transactions and financingis framed as an essential part of functioning innovation systems designed to feed the world [125]. The domestication of agro-food innovations in sustainability transition is a sophisticated process as a large number of users are illiterate and risk averse, leading to high transaction cost for the market paradigm and behaviors are embedded with community norms and dominant rules [126,127]. As a consequence, aside from market sophistication, social movements led by civil society are useful to facilitate such events and activities.

User sophistication suggests promising opportunities. It also implies that it is necessary reconfigure agro-food systems by investigating common public perceptions and rallying user innovation. Agro-food innovations towards sustainability are often designed to solve problems and achieve better "command and control" in production management; the knowledge regime favors codified information and technologies [128]. However, agricultural sustainability is not entirely individual practices but rather social-technical practice and interaction among multiple actors, involving cognitions, values, habits and norms. Agro-food innovations are not only influenced by the supply of knowledge, but also by user domestication. A burgeoning body of examples show user innovations in alternative forms of agrifood systems, such as community-support-agriculture, farmers markets and farm-to-school [20,129-131].

\subsection{Entrepreneurial Activities}

Entrepreneurship constitutes the core of functional views of system innovation. Scholarly research about innovation and the history of technology highlights the fact that large incumbent firms often do not succeed in transforming their scientific or industrial (explicit) knowledge into innovation [132]. Innovation has been viewed as an entrepreneurial process of identifying and exploiting opportunities in the marketplace by assembling and organizing resources [80,133]. It is also a cognitive loop in which creative entrepreneurs build and transform tacit and embedded knowledge and guide experimental actions [133]. The nature of entrepreneurship is to exploit hidden and tacit knowledge with a new venture, and entrepreneurs are therefore viewed as the 'knowledge filter' in the innovation process [134]. This knowledge-based view of innovation argues that the competitive difference between firms and nations is the result of the entrepreneurial process that creates and applies private sector tacit knowledge [135].

Entrepreneurial activities are crucially important for niche dynamics in sustainability transition. In niches, entrepreneurs face small and unstable markets, limited resources and untapped opportunities. The rules are dispersed and there is limited structuration of activities and much uncertainty. The selection criteria for small market niches are different from the existing regime; new technologies, markets and user preferences needed to be co-constructed [118]. Entrepreneurial action transforms extant reality into new markets through a chain of stakeholder commitments over time, and the end-product of the process is inherently unpredictable [136].

The role of social entrepreneurship is emerging in agro-food sustainability. Social entrepreneurship is a global emerging phenomenon focusing on addressing enduring social and development challenges through innovation $[137,138]$. Unlike mainstream entrepreneurial ventures in business, the notion of social entrepreneurship articulates and positions unmet social needs and problems at the heart of business models $[139,140]$ (p. 68). 
Aside from independent entrepreneurship (as in mainstream business), social entrepreneurship can also emerge "from the inside out", leveraging networks, brands and resources from existing public organizations and private incumbents to scale up [141]. Social entrepreneurship differs from philanthropy because it is an organized process that creates economic value, although both undertake mission-driven activities. Notwithstanding academic debates about the nature of social entrepreneurship and its variety of different applications [142,143], the concept of social entrepreneurship has been widely shared and has gained interest and investment from global sustainable development [144] and agricultural transformation communities [145].

The blending of commercial, social and environmental interests constitutes the core value proposition of the business model of entrepreneurial innovation. When dealing with sustainability transition of multiple actors, entrepreneurial organizations interact with not only intended users or clients, but also with third-payers, donors, volunteers and workers. Entrepreneurs need to have a plausible value proposition for each group they interact with [140]. When entrepreneurial organizations commit themselves to a sustainability vision-sometimes called 'ecopreneurs' when they on the environment or 'social entrepreneurs' when they target enduring social problems-they combine business and social value propositions using a hybrid business model and value creation [146].

\subsection{Directionality}

Directionality is at the heart of framing agro-food innovation and sustainability transition. According to the conventional framing of innovation, societal problems are assumed to be addressed directly by productivity enhancements and R\&D investment, or indirectly by strengthened capacities and networking externalities [30]. Nonetheless, the societal goals of sustainable development and transition are not just identified objectives to pursue or to leverage, but necessitate experimentation and learning about underlying assumptions and values. Development and sustainability thinking recognizes a wide range of global challenges-such as poverty, climate change, energy, mobility, food, water and healthcareand proposes global initiatives that call for greener production, increased social justice, a fairer distribution of welfare, sustainable consumption patterns and alternative models of economic growth $[147,148]$.

Given that the concept of sustainability is so formidable, in that it is an all-encompassing set of values, directionality advocates that have open and plural choices should be one of the principles for social appraisal. In the domain of public policy, distributed pressures may assert the intellect of relatively privileged social actors, such as mainstream investors, regulators, high-impact entrepreneurs and key opinion leaders [149]. These established socio-technical configurations quickly acquire momentum and develop into the 'regime' and then in turn come to exercise a degree of 'autonomy' at the expense of alternative and less privileged configurations, for example in cases like genetic modification [150] and food additives [151]. Other discourses on 'sustainability' — such as climate change and the low carbon economy - are characterized by technology-determinism and 'no alternatives' rhetoric [152]. It is in this way that the global discourse on sustainability is subject to rhetorical processes such as "whatever happens to emerge from dominant structures of power and privilege in existing institutions and markets is implicitly held to constitute self-evident 'progress'" [153] (p. 27). Directionality is proposed as a principle for social appraisal, in addition to inclusivity, rigorousness, transparency and accessibility [154].

When it comes to framing agro-food innovation, directionality underscores the reflexive thinking and design of alternative food and farming systems towards sustainability and resilience. In the early years of agricultural modernization, techniques were developed to maximize output, improve production efficiency and ensure consistency and predictability to achieve better "command and control" [128]. However, farming systems are open, complex, adaptive and inherently dynamic systems, meaning that such techniques were not completely appropriate. As a result, alternative views on how to reconfigure food 
and agricultural systems were developed over the past 30 years, and agro-food system innovations have become emerging and evolving research fields [6].

While some of 'alternative' approaches to agricultural modernization were developed into global programs and even communities, most remain outside or at the fringe of the existing regime and the 'mainstream'. One example is 'agroecology', which defines the agrofood system as a co-evolution of nature and societies and reframes the relationship between farming systems and environment [155]. Recently, the notion has entered the discourse of international organizations and been advocated by Food and Agriculture Organization of the United Nations (FAO) as a comprehensive approach to the "future of agriculture" and a pathway to achieving the SDGs $[156,157]$. In addition to agroecology, alternative agro-food movements have entered the public consciousness, such as community support agriculture [158,159], alternative food networks [130,160] and food sovereignty [161-164]. While these notions move beyond a focus on productivity when it comes to food security and advocate for social justice and knowledge learning for sustainability [165], they fail to address immediate problems and build lasting and transformative institutions or social structures when put into practice [166-168]. Some scholars stated that alternative agro-food movements are internally inconsistent with social justice as they inadvertently reproduce exclusions and run the risk of "defensive localism" when put into practice [76]; they are rarely actually put into practice, however, due to the dependence of civil society and the strong technocratic leaning of capitalist agriculture [169].

Directionality advocates for the open-ended formulation of policies and partnerships among public, private and civil society in AIS. When innovations are conceptualized as a process of knowledge creation and diffusion (as in Frame 1), policy formulation is mainly achieved through partnership and interaction between governments and the scientific community [30]. From the perspective of national innovation systems, while multiple stakeholders are involved, a reduced form of user-entrepreneur is at the center and other agents play mostly facilitating roles. In the construction of transformative innovations, a wide range of stakeholders-users, entrepreneurs, legitimators, technocratic experts and civil society-come up with new solutions to arrive at the desired outcomes. To democratize the knowledge regime, civil society plays an important role in introducing reflexivity and guarding directionality [18].

\subsection{Reflexive Evaluation}

In complex and dynamic systems of sustainability transition (such as evolving farming systems), reflexivity is at the heart of research, practices and policy analysis. Reflexivity sensitizes the complex relationship between the processes of knowledge production and the various contexts of such processes, as well as the involvement of the knowledge producer and practitioners [170]. Reflexivity does not propose any concrete methods for transition management but rather focuses on its ontology and epistemology [16]. Reflexive practice focuses on two main forms of action: careful interpretation (first-order processes) and reflection (such as interpreting the interpretation, second-order processes) [14]. Taking agro-food innovation as an example, second-order reflexive practices provide alternative descriptions and interpretations of the concept, challenging efforts to consolidate a particular orthodox understanding of farming (such as the intensive use of synthesized agro-chemicals or the agrofood system of mass production and extensive distribution). Reflexivity concerns both 'what' and 'why (not)'.

The absence of reflexivity fails the discourse of sustainability and innovation as a form of normative rhetoric. Reflexivity has been criticized for its "enlightening" nature but inadequate practical and analytical guidelines [171]. Nonetheless, recent studies found it has fundamental value for transforming food and agriculture towards sustainability and resilience $[89,172,173]$. For example, in a reflexive design that aimed to transform the Dutch livestock industry towards sustainability, researchers discovered a number of constraints that hampered their efforts, such as the strong influence of research-led thinking, inadequate participatory design and fragmentation of various home (sub)disciplines. 
The interactions were greatly ingrained and locked in an established regime, but it was valuable for the researchers to be able to identify them as constraints [89]. Reflexivity in sustainability transition is more than an "art of facilitation" or "learning architecture' but a societal need and infrastructure that serves as a coordinating device for collective sensemaking, imagination and enactment [174].

Reflexive evaluation is an ontological approach to function reflexivity. Given the characteristics of sustainability transition (namely having multi-actors at different levels and scales, being dynamic, uncertain, embedded in context and trans-disciplinary and having vague boundaries), it is difficult to gather indicators and data needed for effective policy making [19]. Unlike conventional monitoring and evaluation (M\&E) approaches that focus on measuring the attainment of intended outcomes and tracking preconceived performance indicators (summative or formative), reflexive evaluation frames innovations as a complexity construct and views evaluations as a 'double-loop learning' process. In essence, a single-loop process follows a problem-detection-correction course. In doubleloop learning, evaluation goes beyond the linear logic of problem-solving and involves "questioning the assumptions, policies, practices, values, and system dynamics that led to the problem" in the first place and "intervening in ways that involve the modification of underlying system relationships and functioning" [33] (p. 11). Just as the complexitysensitive methodology of evaluation has been echoed by social-psychological studies: innovation has been found to be a cognitive capability of adaptive learning, be it individual or collective [175].

As a functional construct of agro-food innovation, reflexive evaluation can be aligned with other components as a form of governance. Reflexive thinking views agro-food transition as a form of system innovation, and its evolution is linked to the open-ended nature of participatory processes and continuous feedback between formulating normative strategies and reflecting on these strategies. This lays foundations for directionality. Meanwhile, entrepreneurial activities that are embedded in reflexive evaluation facilitate experiments and knowledge generation. As transformation reshapes the boundary between science, policy and civil society, reflexive evaluation plays an important role in coordinating and orchestrating various actors in 'dual track' governance, i.e., top-down in transition management and bottom-up in strategic niche management [176].

\section{Conclusions}

Agriculture and food are probably the sectors that are most heavily intertwined with the sustainable development goals of the United Nations. While the sectors have been analyzed as both areas for hope and concern, innovation in agriculture and food has lagged behind innovation in other sectors. To remove lock-ins and to fuel changes at the societal scale, an appropriate conceptualization of innovation for agriculture and food is needed.

This research synthesizes a conceptual framework that (re)defines sustainability transition using a complexity construct of an adaptive cycle of system change. Panarchical views on sustainability transition reconcile the opposing pathways of top-down and bottom-up, and consider the system at every level capable of enabling and constraining innovation. Built on multi-level perspectives of sustainability transition, the structural construct of agricultural innovation system innovation is framed using four components, namely actors and communities, interaction and intermediaries, coherence and connectedness and regimes rules and landscape. Drawing on broad inputs from different schools of thought, the functional construct of system innovation for food and agriculture is framed using five components, namely knowledge management, user sophistication, entrepreneurial activities, directionality and reflexive evaluation.

This article has a special value for understanding the system syndromes of lock-ins and resistance to change in food and agriculture. To overcome inertia and challenge the status quo, it is imperative to create an ecosystem in which different approaches can be equitably developed and evolve [177]. This kind of thinking about the ecosystem goes beyond the architectural construct of the agricultural innovation system as a seamless web in which 
various components are combined in order to achieve functionalities. It also goes beyond the functional roles of networking, standardization or intermediaries. It recognizes and emphasizes the role of power in shaping directionality (and alternatives) in innovation communities and facilitates interactions between the niche and socio-technical regimes. Recent conceptualizations of innovation in food and agriculture started to acknowledge the social and adaptive processes of sustainability transition, including the past situation $[35,128,178]$ and capacity development [21]. Some international organizations, such as FAO and OECD, are reflecting agro-food innovation through systemic perspectives $[2,179,180]$. This article adds value to these global and territorial initiatives by offering a conceptual framework. Its applied value includes, but is not limited to, policy formulation, normative constructions of agricultural innovation systems and analytic tools for capacity building and assessment.

Funding: The author acknowledges funding support from National Natural Science Foundation of China (71573209; 71661147001), National Key R\&D Program of China (2016YFD0201303), National Social Science Foundation (16ZDA021) and Chinese Academy of Agricultural Sciences (CAAS-ASTIP2016-AII).

Institutional Review Board Statement: Not applicable.

Informed Consent Statement: Not applicable.

Data Availability Statement: Not applicable.

Conflicts of Interest: The authors declare no conflict of interest.

\section{References}

1. FAO. The Future of Food and Agriculture: Trends and Challenges; Food and Agriculture Organization of the United Nations (FAO): Rome, Italy, 2017.

2. FAO. Agroecological and Other Innovative Approaches for Sustainable Agriculture and Food Systems that Enhance Food Security and Nutrition. A Report by The High Level Panel of Experts (HLPE) on Food Security and Nutrition (FSN); Food and Agriculture Organization of the United Nations (FAO): Rome, Italy, 2019.

3. Schanbacher, W.D. The Global Conflict between Food Security and Food Sovereignty; Praeger Publisher: Santa Barbara, CA, USA, 2010.

4. Collinson, M. A History of Farming Systems Research; CABI: Oxfordshire, UK, 2000.

5. OECD. Improving Agricultural Knowledge and Innovation Systems; OECD Conference Proceedings; OECD Publishing: Paris, France, 2012.

6. Darnhofer, I.; Gibbon, D.; Dedieu, B. Farming Systems Research: An approach to inquiry. In Farming Systems Research into the 21st Century: The New Dynamic; Darnhofer, I., Gibbon, D., Dedieu, B., Eds.; Springer: Dordrecht, The Netherlands, 2012 ; pp. 3-31.

7. Barbier, M.; Elzen, B. System Innovations, Knowledge Regimes, and Design Practices towards Transitions for Sustainable Agriculture; Inra: Paris, France, 2012.

8. Klerkx, L.; Begemann, T. Supporting food systems transformation: The what, why, who, where and how of mission-oriented agricultural innovation systems. Agric. Syst. 2020, 184, 102901. [CrossRef] [PubMed]

9. Elzen, B.; Augustyn, A.M.; Barbier, M.; Mierlo, B.V. AgroEcological Transitions: Changes and Breakthroughs in the Making; Wageningen University \& Research, Applied Arable and Vegetable Research: Wageningen, The Netherlands, 2017. [CrossRef]

10. Díaz-García, C.; González-Moreno, Á.; Sáez-Martínez, F.J. Eco-innovation: Insights from a literature review. Innov. Manag. Policy Pract. 2015, 17, 6-23. [CrossRef]

11. Köhler, J.; Geels, F.W.; Kern, F.; Markard, J.; Onsongo, E.; Wieczorek, A.; Alkemade, F.; Avelino, F.; Bergek, A.; Boons, F.; et al. An agenda for sustainability transitions research: State of the art and future directions. Environ. Innov. Soc. Transit. 2019, 31, 1-32. [CrossRef]

12. Grin, J.; Rotmans, J.; Schot, J.; Geels, F.; Loorbach, D. Transitions to Sustainable Development: New Directions in the Study of Long Term Transformative Change; Routledge: New York, NY, USA, 2010.

13. Geels, F.W. The multi-level perspective on sustainability transitions: Responses to seven criticisms. Environ. Innov. Soc. Transit. 2011, 1, 24-40. [CrossRef]

14. Voß, J.-P.; Kemp, R. Sustainability and reflexive governance: Introduction. In Reflexive Governance for Sustainable Development; Voß, J.-P., Bauknecht, D., Kemp, R., Eds.; Edward Elgar: Cheltenham, UK, 2006.

15. Loorbach, D. Transition management for sustainable development: A prescriptive, complexity-based governance framework. Gov. Int. J. Policy Adm. Inst. 2010, 23, 161-183. [CrossRef]

16. Geels, F.W. Ontologies, socio-technical transitions (to sustainability), and the multi-level perspective. Res. Policy 2010, 39, 495-510. [CrossRef]

17. Schlaile, M.P.; Urmetzer, S.; Blok, V.; Andersen, A.D.; Timmermans, J.; Mueller, M.; Fagerberg, J.; Pyka, A. Innovation systems for transformations towards sustainability? Taking the normative dimension seriously. Sustainability 2017, 9, 2253. [CrossRef] 
18. Buurma, J.; Hoes, A.-C.; Greef, K.d.; Beekman, V. Role of NGOs in system innovation towards animal friendly pork production in the Netherlands. In AgroEcological Transitions: Changes and Breakthroughs in the Making; Elzen, B., Augustyn, A.M., Barbier, M., Mierlo, B.v., Eds.; Wageningen University \& Research, Applied Arable and Vegetable Research: Wageningen, The Netherlands, 2017. [CrossRef]

19. Fukasaku, Y. The need for environmental innovation indicators and data from a policy perspective. In Towards Environmental Innovation Systems; Weber, M., Hemmelskamp, J., Eds.; Springer: Berlin/Heidelberg, Germany; New York, NY, USA, 2005.

20. Beckie, M.A.; Kennedy, E.H.; Wittman, H. Scaling up alternative food networks: Farmers' markets and the role of clustering in western Canada. Agric. Hum. Values 2012, 29, 333-345. [CrossRef]

21. Tropical Agriculture Platform. Common Framework on Capacity Development for Agricultural Innovation Systems: Synthesis Document; CAB International: Wallingford, UK, 2016.

22. Solow, R. Technical change and the aggregate production function. Rev. Econ. Stat. 1957, 39, 312-320. [CrossRef]

23. Sagasti, F.R. The two civilizations and the process of development. Prospects 1980, 10, 123-139. [CrossRef]

24. Lundvall, B.Å. National Systems of Innovation: Towards a Theory of Innovation and Interactive Learning; Pinter Publishers: London, UK, 1992.

25. Freeman, C. Japan: A new national system of innovation. In Technical Change and Economic Theory; Dosi, G., Freeman, C., Nelson, R.R., Silverberg, G., Soete, L., Eds.; Pinter Publishers: London, UK, 1988; pp. 330-348.

26. Stokes, D.E. Pasteur's Quadrant_Basic Science and Technological Innovation; Brookings Institution Press: Washington, DC, USA, 1997.

27. Dasgupta, P.; David, P.A. Toward a new economics of science. Res. Policy 1994, 23, 487-521.

28. Lundvall, B.A. Innovation as an interactive process: From user-producer interaction to national systems of innovation. In Technical Change and Economic Theory; Dosi, G., Freeman, C., Nelson, R.R., Silverberg, G., Soete, L., Eds.; Pinter Publishers: London, UK, 1988.

29. Von Hippel, E. Sticky information' and the locus of problem solving: Implications for innovation. Manag. Sci. 1994, 40, 429-439. [CrossRef]

30. Schot, J.; Steinmueller, E. Three frames for innovation policy: R\&D, systems of innovation and transformative change. Res. Policy 2018, 47, 1554-1567.

31. Zimmerman, B.; Glouberman, S. Complicated and complex systems: What would successful reform of Medicare look like? In Health Care Services and the Process of Change; Forest, P.-G., McIntosh, T., Marchildon, G., Eds.; University of Toronto Press: Toronto, ON, Canada, 2004; pp. 21-53.

32. Zimmerman, B.; Lindberg, C.; Plsek, P. Edgeware: Insights from Complexity Science or Health Care Leaders; VHA, Inc.: Irving, TX, USA, 1998.

33. Patton, M.Q. Developmental Evaluation: Applying Complexity Conceputs to Enhance Innovation and Use; The Guilford Press: London, UK, 2011.

34. Cabaj, M. Understanding Poverty as a Complex Issue and Why That Matters; Caledon Institute for Social Policy: Ottawa, ON, Canada, 2009.

35. Noe, E.; Alrøe, H.F. Observing farming systems: Insights from social systems theory. In Farming Systems Research into the 21st Century: The New Dynamic; Darnhofer, I., Gibbon, D., Dedieu, B., Eds.; Springer: Dordrecht, The Netherlands, 2012 ; pp. $387-404$.

36. Gunderson, L.H.; Holling, C.S. Panarchy: Understanding Transformations in Human and Natural Systems; Island Press: Washington, DC, USA, 2002.

37. Holling, C.S. Understanding the complexity of economic, ecological and social systems. Ecosystems 2001, 4, 390-405. [CrossRef]

38. Weber, M.; Hemmelskamp, J. Towards Environmental Innovation Systems; Springer: Berlin/Heidelberg, Germany; New York, NY, USA, 2005.

39. Hendriks, C. On inclusion and network governance: The democratic disconnect of Dutch energy transitions. Public Adm. 2008, 86, 1009-1031. [CrossRef]

40. Geels, F.W.; Schot, J. Typology of sociotechnical transition pathways. Res. Policy. 2007, 36, 399-417. [CrossRef]

41. Dahle, K. When do transformative initiatives really transform? A typology of different paths for transition to a sustainable society. Futures 2007, 39, 487-504. [CrossRef]

42. Schot, J.; Geels, F.W. Strategic niche management and sustainable innovation journeys: Theory, findings, research agenda, and policy. Technol. Anal. Strateg. Manag. 2008, 20, 537-554. [CrossRef]

43. Caniels, M.C.J.; Romijn, H.A. Strategic niche management: Towards a policy tool for sustainable development. Technol. Anal. Strateg. Manag. 2008, 20, 245-266. [CrossRef]

44. Kemp, R.; Schot, J.; Hoogma, R. Regime shifts to sustainability through processes of niche formation: The approach of strategic niche management. In Innovation, Technology and Economic Change; Elgar Research Collection, International Library of Critical Writings in Economics; Elgar: Cheltenham, UK; Northampton, MA, USA, 2015; Volume 306, pp. 790-810.

45. Colin, J.-P.; Crawford, E.W. Research on Agricultural Systems: Accomplishments, Perspectives and Issues; Nova Science: Huntington, UK, 2000.

46. Brossier, J.; Hubert, H. Integration of bio-technical, economic and social sciences. In Technical and social systems approaches for sustainable rural development. In Proceedings of the 2nd European IFSA Symposium, Granada, Spain, 2000; pp. 41-65. Available online: http:/ / ifsa.boku.ac.at/cms /index.php?id=42 (accessed on 25 November 2020).

47. Sorensen, T. Australian agricultural R\&D and innovation systems. Int. J. Foresight Innov. Policy 2011, 7, $192-212$. 
48. Spielman, D.; Ekboir, J.; Davis, K. The art and science of innovation systems inquiry: Applications to sub-Saharan African agriculture. Technol. Soc. 2009, 31, 399-405. [CrossRef]

49. Hall, A.J. Public private sector partnerships in a system of agricultural innovation: Concepts and challenges. Int. J. Technol. Manag. Sustain. Dev. 2006, 5, 3-20. [CrossRef]

50. Birner, R.; Davis, K.; Pender, J.; Nkonya, E.; Anandajayasekeram, P.; Ekboir, J.; Mbabu, A.; Spielman, D.J.; Horna, D.; Benin, S.; et al. From best practice to best fit: A framework for designing and analyzing pluralistic agricultural advisory services worldwide. J. Agric. Educ. Ext. 2009, 15, 341-355. [CrossRef]

51. Hekkert, M.P.; Suur, R.A.A.; Negro, S.O.; Kuhlmann, S.; Smits, R.E.H.M. Functions of innovation systems: A new approach for analysing technological change. Technol. Forecast. Soc. Chang. 2007, 74, 413-432. [CrossRef]

52. Bergek, A.; Jacobsson, S.; Carlsson, B.; Lindmark, S.; Rickn, A. Analyzing the functional dynamics of technological innovation systems: A scheme of analysis. Res. Policy 2008, 37, 407-429. [CrossRef]

53. Kammili, T.; Hubert, B.; Tourrand, J.-F. A paradigm shift in livestock management: From resource sufficiency to functional integrity; Lirac, Cardère: Avignon, France, 2011.

54. Klerkx, L.; Leeuwis, C. Matching demand and supply in the agricultural knowledge infrastructure: Experiences with innovation intermediaries. Food Policy 2008, 33, 260-276. [CrossRef]

55. Klerkx, L.; Aarts, N.; Leeuwisa, C. Adaptive management in agricultural innovation systems: The interactions between innovation networks and their. Agric. Syst. 2010, 103, 390-400. [CrossRef]

56. Elzen, B.; Spoelstra, S. Learning and experimentation strategy: Outline of a method to develop sustainable livestock production systems. In Methods and Procedures for Building Sustainable Farming Systems. Applications in the European Context; Marta-Costa, A., Soares da Silva, E., Eds.; Springer: Dordrecht, The Netherlands, 2012; pp. 91-105.

57. Leeuwis, C.; Aarts, N. Rethinking communication in innovation processes: Creating space for change in complex systems. J. Agric. Educ. Ext. 2011, 17, 21-36. [CrossRef]

58. Tropical Agriculture Platform. Common Framework on Capacity Development for Agricultural Innovation Systems: Conceptual Background; CAB International: Wallingford, UK, 2016.

59. Gidden, A. Central Problems in Social Theory: Action, Structure, and Contradiction in Social Analysis; University of California Press: Berkeley, CA, USA, 1979.

60. Scott, W.R. Institutions and Organizations; Sage Publications: London, UK; New Delhi, India, 1995.

61. Grin, J.; van de Graaf, H. Technology assessment as learning. Sci. Technol. Hum. Values 1996, 20, 72-99. [CrossRef]

62. Geels, F.W. From sectoral systems of innovation to socio-technical systems Insights about dynamics and change from sociology and institutional theory. Res. Policy 2004, 33, 897-920. [CrossRef]

63. Geels, F.W. Technological transitions as evolutionary reconfiguration processes: A multi-level perspective and a case-study. Res. Policy 2002, 31, 1257-1274. [CrossRef]

64. Rivera, W.M.; Alex, G.; Hanson, J.; Birner, R. Enabling agriculture: The evolution and promise of agricultural knowledge frameworks. In Proceedings of the Association for International Agricultural and Extension Education (AIAEE) 22nd Annual Conference Proceedings, Clearwater Beach, FL, USA, 14-19 May 2006.

65. Hall, A. Partnerships in agricultural innovation: Who puts them together and are they enough. In Improving Agricultural Knowledge and Innovation Systems: OECD Conference Proceedings; OECD Publishing: Paris, France, 2012.

66. Smith, A.; Raven, R. What is protective space? Reconsidering niches in transitions to sustainability. Res. Policy 2012, 41, 1025-1036. [CrossRef]

67. Rotmans, J.; Loorbach, D. Towards a better understanding of transitions and their governance: A systemic and reflexive approach. In Transitions to Sustainable Development: New Directions in the Study of Long Term Transformative Change; Grin, J., Rotmans, J., Schot, J., Geels, F., Loorbach, D., Eds.; Routledge: New York, NY, USA, 2010.

68. Elzen, B.; Christine, B.; Mierlo, V.; Leeuwis, C. Anchoring of innovations: Assessing Dutch efforts to harvest energy from glasshouses. Environ. Innov. Soc. Transit. 2012, 5, 1-18. [CrossRef]

69. Röling, N.; Jiggins, J. The ecological knowledge system. In Facilitating Sustainable Agriculture: Participatory Learning and Adaptive Management in Times of Environmental Uncertainty; Röling, N., Wagermakers, M.A., Eds.; Cambridge University Press: Cambridge, UK, 1998; pp. 283-311.

70. Williamson, O.E. The economic Institutions of Capitalism; The Free Press: New York, NY, USA, 1985.

71. Menard, C. Organization and governance in the agrifood sector: How canwe capture their variety? Agribus. Int. J. 2018, 34, 142-160. [CrossRef]

72. Ménard, C.; Klein, P.G. Organizational issues in the agrifood sector: Toward a comparative approach. Am. J. Agric. Econ. 2004, 86, 750-755. [CrossRef]

73. Klerkx, L.; Leeuwis, C. The emergence and embedding of innovation brokers at different innovation system levels: Insights from the Dutch Agricultural Sector. Technol. Forecast. Soc. Chang. 2009, 76, 849-860. [CrossRef]

74. Klerkx, L.; Hall, A.; Leeuwis, C. Strengthening agricultural innovation capacity: Are innovation brokers the answer? Int. J. Agric. Resour. Gov. Ecol. 2009, 8, 409-438. [CrossRef]

75. Marin, L.E.M.; Russo, V. Re-localizing 'legal' food: A social psychology perspective on community resilience, individual empowerment and citizen adaptations in food consumption in Southern Italy. Agric. Hum. Values 2016, 33, 179-190. [CrossRef]

76. Winter, M. Embeddedness, the new food economy and defensive localism. J. Rural Stud. 2003, 19, 23-32. [CrossRef] 
77. World Bank. World Bank Report: Digital Dividends; The World Bank: Washington, DC, USA, 2016.

78. Burns, T.R.; Flam, H. The Shaping of Social Organization: Social Rule System Theory with Applications; Sage Publications: London, UK, 1987.

79. Williamson, O.E. Calculativeness, trust, and economic organization. J. Law Econ. 1993, 36, 453-486. [CrossRef]

80. Kirzner, I.M. Entrepreneurial discovery and the competitive market process: An Austrian approach. J. Econ. Lit. 1997, 35, 60-85.

81. Sarasvathy, S.D. Causation and effectuation: Toward a theoretical shift from economic inevitability to entrepreneurial contingency. Acad. Manag. Rev. 2001, 26, 243-263. [CrossRef]

82. Baker, T.; Nelson, R.E. Creating something from nothing: Resource construction through entrepreneurial bricolage. Adm. Sci. $Q$. 2005, 50, 329-366. [CrossRef]

83. Aldrich, H.E.; Kenworthy, A.L. The accidental entrepreneur: Campbellian antinomies and organizational foundings. In Variations in Organization Science: In Honor of Donald T. Campbell; Baum, J.A.C., McKelvey, B., Eds.; Sage: Thousand Oaks, CA, USA, 1999; pp. 19-33.

84. Alvarez, S.A.; Barney, J.B. Discovery and creation: Alternative theories of entrepreneurial action. Strateg. Entrep. J. 2007, 1, 11-26. [CrossRef]

85. Rivera, W.M.; Alex, G. The continuing role of government in pluralistic extension systems. J. Int. Agric. Ext. Educ. 2004, 11, 41-51. [CrossRef]

86. Fuenfschilling, L.; Truffer, B. The structuration of socio-technical regimes-Conceptual foundations from institutional theory. Res. Policy 2014, 43, 772-791. [CrossRef]

87. Bui, S.; Cardona, A.; Lamine, C.; Cerf, M. Sustainability transitions: Insights on processes of niche-regime interaction and regime reconfiguration in agri-food systems. J. Rural Stud. 2016, 48, 92-103. [CrossRef]

88. Howells, J. Intermediation and the role of intermediaries in innovation. Res. Policy 2006, 35, 715-728. [CrossRef]

89. Grin, J.; Felix, F.; Bos, A.P.; Spoelstra, S. Practices for reflexive design: Lessons from a Dutch programme on sustainable agriculture. Int. J. Foresight Innov. Policy 2004, 1, 126-149. [CrossRef]

90. Murray, P.; Blackman, D. Managing innovation through social architecture, learning, and competencies: A new conceptual approach. Knowl. Process Manag. 2006, 13, 132-143. [CrossRef]

91. Savage, G.; Hilton, C. A critical view of facilitating labor-management collaboration. Group Facil. Res. Appl. J. 2001, 3, 47-55.

92. Elzen, B.; Barbier, M.; Cerf, M.; Grin, J. Stimulating transitions towards sustainable farming systems. In Farming Systems Research into the 21st Century: The New Dynamic; Darnhofer, I., Gibbon, D., Dedieu, B., Eds.; Springer: Dordrecht, The Netherlands, 2012; pp. 431-455.

93. Smith, A. Translating sustainabilities between green niches and socio-technical regimes. Technol. Anal. Strateg. Manag. 2007, 19, 427-450. [CrossRef]

94. Berkhout, F.; Smith, A.; Stirling, A. Socio-technological regimes and transition contexts. In System Innovation and the Transition to Sustainability: Theory, Evidence and Policy; Elzen, B., Geels, F.W., Green, K., Eds.; Edward Elgar Publishing, Inc.: Northampton, MA, USA; Cheltenham, UK, 2004; pp. 48-75.

95. Habermas, J. Popular sovereignty as procedure. In Between Facts and Norms: Contributions to a Discourse Theory of Law and Democrac; Habermas, J., Ed.; MIT Press: Cambridge, MA, USA, 1996; pp. 463-490.

96. Rip, A.; Kemp, R. Technological change. In Human Choice and Climate Change; Rayner, S., Malone, E.L., Eds.; Battelle Press: Columbus, OH, USA, 1998; Volume 2, pp. 327-399.

97. Kemp, R.; Loorbach, D.; Rotmans, J. Transition management as a model for managing processes of co-evolution towards sustainable development. Int. J. Sustain. Dev. World Ecol. 2007, 14, 78-91. [CrossRef]

98. Fisher, G. Effectuation, causation, and bricolage: A behavioral comparison of emerging theories in entrepreneurship research. Entrep. Theory Pract. 2012, 36, 1019-1051. [CrossRef]

99. Desa, G. Resource mobilization in international social entrepreneurship: Bricolage as a mechanism of institutional transformation. Entrep. Theory Pract. 2012, 36, 727-751. [CrossRef]

100. Desa, G. Optimization or bricolage? Overcoming resource constraints in global social entrepreneurship. Strateg. Entrep. J. 2013, 7, 26-49. [CrossRef]

101. Sahal, D. Technological guideposts and innovation avenues. Res. Policy 1985, 14, 61-82. [CrossRef]

102. Negro, S.O.; Hekkert, M.P. Explaining the success of emerging technologies by innovation system functioning: The case of biomass digestion in Germany. Technol. Anal. Strateg. Manag. 2008, 20, 465-482. [CrossRef]

103. Jacobbson, S.; Johnson, A. The diffusion of renewable energy technology: An analytical framework and key issues for research. Energy Policy 2000, 28, 625-640. [CrossRef]

104. Green, K.; Shackley, S.; Dewick, P.; Miozzo, M. Long-wave theories of technological change and the global environment. Glob. Environ. Chang. 2002, 12, 79-81. [CrossRef]

105. Perez, C. Technological revolutions, paradigm shifts and socio-institutional change. In Globalization, Economic Development and Inequality: An Alternative Perspective; Reinert, E.S., Ed.; Elgar: Cheltenham, UK, 2004; pp. 217-242.

106. World Bank. Agricultural Innovation System: From Diagnostics to Operational Practices; Agriculture and Rural Development Discussion Paper 38; World Bank: Washington, DC, USA, 2008.

107. Thornton, P.; Schuetz, T.; Förch, W.; Cramer, L.; Abreu, D.; Vermeulen, S.; Campbell, B. Responding to global change: A theory of change approach to making agricultural research for development outcome-based. Agric. Syst. 2017, 152, 145-153. [CrossRef] 
108. Cook, S.D.; Brown, J.S. Bridging epistemologies: The generative dance between organizational knowledge and organizational knowing. Organ. Sci. 1999, 10, 381-400. [CrossRef]

109. Nonaka, I. Theory of organizational knowledge creation. Organ. Sci. 1994, 5, 14-37. [CrossRef]

110. Gamble, P.R.; Blackwell, J. Knowledge Management: A State of the Art Guide; Kogan Page Ltd.: London, UK, 2001.

111. CRISP. Codification of Tacit Knowledge and Its Impact on the Strengthening of Livestock Sector Related Innovation Capacity; Center for Research on Innovation and Science Policy: Hyderabad, India, 2007.

112. Rajendran Muthuveloo, N.S.; Teoh, A.P. The impact of tacit knowledge management on organizational performance: Evidence from Malaysia. Asia Pac. Manag. Rev. 2017, 22, 192-201.

113. Lesser, W. Intellectual property rights and concentration in agricultural biotechnology. AgBioForum 1998, 1, 56-61.

114. Muyldermans, D. Public-private partnerships: The role of the private sector. In Improving Agricultural Knowledge and Innovation Systems; OECD Conference Proceedings; OECD Publishing: Paris, France, 2012.

115. Etzkowitz, H.; Leydesdorff, L. The dynamics of innovation: From national systems and "Mode 2" to a triple helix of UniversityIndustry-Government relations. Res. Policy 2000, 29, 109-123. [CrossRef]

116. Malerba, F. Sectoral systems of innovation. Res. Policy 2002, 31, 247-264. [CrossRef]

117. Lie, M.; Sørensen, K.H. Making Technology Our Own: Domesticating Technology into Everyday Life; Scandinavian University Press: Oslo, Norway, 1996.

118. Oudshoorn, N.; Pinch, T. How Users Matter: The Co-Construction of Users and Technology; MIT Press: Cambridge, MA, USA, 2003.

119. Kline, R.; Pinch, T. Users as agents of technological change: The social construction of the automobile in the rural United States. Technol. Cult. 1996, 37, 763-795. [CrossRef]

120. Schwartz-Cowan, R. The consumption junction: A proposal for research strategies in the sociology of technology. In The Social Construction of Technological Systems: New Directions in the Sociology and History of Technology; Bijker, W.E., Hughes, T.P., Pinch, T.J., Eds.; MIT Press: Cambridge, MA, USA, 1987.

121. Lynn, G.S.; Morone, J.G.; Paulson, A.S. Marketing and discontinuous innovation: The probe and learn process. Calif. Manag. Rev. 1996, 38, 8-37. [CrossRef]

122. Stroh, D.P. Systems Thinking for Social Change; Chelsea Green Publishing: Chelsea, VT, USA, 2015.

123. Funnell, S.C.; Rogers, P.J. Purposeful Program Theory: Effective Use of Theories of Change and Logic Models; Jossey-Bass: Hoboken, NJ, USA, 2011.

124. Mulgan, G.; Leadbeater, C. System Innovation; NESTA: London, UK, 2013.

125. Dutta, S.; Lanvin, B.; Wunsch-Vincent, S. The Global Innovation Index 2017: Innovation Feeding the World; Cornell SC Johnson College of Business: Ithaca, NY, USA; INSEAD (The Business Schoool for the World): Fontainebleau, France; WIPO (World Intellectual Property Organization): Geneva, Switzerland, 2018.

126. Feder, G. Farm size, risk aversion and the adoption of new technology under uncertainty. Oxf. Econ. Pap. 1980, 32, 263-283. [CrossRef]

127. Platteau, J.-P. Institutions, Social Norms, and Economic Development; Routledge: London, UK, 2000.

128. Darnhofer, I.; Bellon, S.; Dedieu, B.; Milestad, R. Adaptiveness to enhance the sustainability of farming systems. Agron. Sustain. Dev. 2010, 30, 545-555. [CrossRef]

129. Allen, P.; Guthman, J. From "old school" to "farm-to-school": Neoliberalization from the ground up. Agric. Hum. Values 2006, 23, 401-415. [CrossRef]

130. Luigi Cembalo, A.L.; Pascucci, S.; Dentoni, D.; Migliore, G.; Verneau, F.; Schifani, G. "Rationally Local”: Consumer participation in alternative food chains agribusiness. Agribusiness 2015, 31, 330-352. [CrossRef]

131. Powell, L.J.; Wittman, H. Farm to school in British Columbia: Mobilizing food literacy for food sovereignty. Agric. Hum. Values 2018, 35, 193-206. [CrossRef]

132. Penrose, E. The Theory of the Growth of the Firm; John Wiley and Sons: New York, NY, USA, 1959.

133. Alvarez, S.A.; Barney, J.B. Opportunities, organizations, and entrepreneurship: Theory and debate. Strateg. Entrep. J. 2008, 2, 171-173. [CrossRef]

134. Acs, Z.J.; Braunerhjelm, P.; Audretsch, D.B.; Carlsson, B. The knowledge spillover theory of entrepreneurship. Small Bus. Econ. 2009, 32, 15-30. [CrossRef]

135. Teece, D.J.; Pisano, G.; Shuen, A. Dynamic capabilities and strategic management. Strateg. Manag. J. 1997, 18, 509-533. [CrossRef]

136. Sarasvathy, S.D.; Dew, N. New market creation through transformation. J. Evol. Econ. 2005, 15, 533-565. [CrossRef]

137. Martin, R.L.; Osberg, S. Social entrepreneurship: The case for definition. Stanf. Soc. Innov. Rev. 2007, 1, $29-39$.

138. Seelos, C.; Mair, J. Social entrepreneurship. The contribution of individual entrepreneurs to sustainable development. SSRN Electron. J. 2005, 3, 69-78. [CrossRef]

139. Mair, J.; Schoen, O. Social Entrepreneurial Business Models: An Exploratory Study; Working Paper No. 610; IESE Business School, University of Navarra: Barcelona, Spain, 2005.

140. Sommerrock, K. Social Entrepreneurship Business Models: Incentive Strategy to Catalyze Public Goods Provision; Palgrave Macmillan: London, UK, 2010.

141. Simanis, E.; Hart, S. Innovation from the inside out. Sloan Manag. Rev. 2009, 50, 77-86.

142. Dacin, M.T.; Dacin, P.A.; Tracey, P. Social entrepreneurship: A critique and future directions. Organ. Sci. 2011, $22,1203-1213$. [CrossRef] 
143. Nicholls, A. The legitimacy of social entrepreneurship: Reflexive isomorphism in a preparadigmatic field. Entrep. Theory Pract. 2010, 34, 611-633. [CrossRef]

144. Borzaga, C.; Defourny, J. The Emergence of Social Enterprise; Routledge: London, UK; New York, NY, USA, 2001.

145. Jia, X.; Desa, G. Social entrepreneurship and impact investment in rural-urban transformation: An orientation to systemic social innovation and symposium findings. Agric. Hum. Values 2020. [CrossRef]

146. Abdelkafi, N.; Hansen, E.G. Ecopreneurs' creation of user business models for green tech: An exploratory study in e-mobility. Int. J. Entrep. Ventur. 2018, 10, 32-55. [CrossRef]

147. OECD. System Innovation: Synthesis Report; OECD: Paris, France, 2015.

148. United Nations. Transforming Our World: The 2030 Agenda for Sustainable Development. 2015. Available online: https:/ / sustainabledevelopment.un.org/post2015/transformingourworld (accessed on 5 June 2019).

149. Brown, N.; Michael, M. A sociology of expectations: Retrospecting prospects and prospecting retrospects. Technol. Anal. Strateg. Manag. 2003, 15, 3-18. [CrossRef]

150. Van den Berg, J.C.J.M.; Holley, J.M. An environmental-economic assessment of genetic modification of agricultural crops. Futures 2002, 34, 807-822. [CrossRef]

151. Millstone, E. Food Additives; Middlesex Penguin: London, UK, 1986.

152. Leach, M.; Scoones, I.; Stirling, A. Governing epidemics in an age of complexity: Narratives, politics and pathways to sustainability. Glob. Environ. Chang. 2010, 20, 369-377. [CrossRef]

153. Stirling, A. Direction, Distribution and Diversity! Pluralising Progress in Innovation, Sustainability and Development; Working Paper; STEPS Centre: Sussex, UK, 2009.

154. Stirling, A.; Mitchell, C. Evaluate power and bias in synthesizing evidence for policy. Nature 2018, 561, 33. [CrossRef]

155. Gliessman, S.R. Agroecology: The Ecology of Sustainable Food Systems; CRC Press: London, UK, 2007.

156. FAO. The 10 Elements of Agroecology: Guiding the Transition to Sustainable Food and Agricultural Systems; United Nations, Food and Agriculture (FAO): Rome, Italy, 2019.

157. FAO. FAO'S Work on Agroecology: A Pathway to Achieving the SDGs; United Nations, Food and Agriculture (FAO): Rome, Italy, 2018.

158. Hinrichs, C.C. Embeddedness and local food systems: Notes on two types of direct agricultural market. J. Rural Stud. 2000, 16, 295-303. [CrossRef]

159. Hayden, J.; Buck, D. Doing community supported agriculture: Tactile space, affect and effects of membership. Geoforum 2012, 43, 332-341. [CrossRef]

160. Forssell, S.; Lankoski, L. The sustainability promise of alternative food networks: An examination through "alternative" characteristics. Agric. Hum. Values 2015, 32, 63-75. [CrossRef]

161. Windfuhr, M.; Jonsen, J. Food Sovereignty: Towards Democracy in Localized Food Systems; ITDG Publishing: Warwickshire, UK, 2005.

162. Agarwal, B. Food sovereignty, food security and democratic choice: Critical contradictions, difficult conciliations. J. Peasant Stud. 2014, 41, 1247-1268. [CrossRef]

163. Edelman, M.; Weis, T.; Baviskar, A.; Borras, S.M., Jr.; Holt-Giménez, E.; Kandiyoti, D.; Wolford, W. Introduction: Critical perspectives on food sovereignty. J. Peasant Stud. 2014, 41, 911-931. [CrossRef]

164. Clendenning, J.D.; Wolfram, H.; Richards, C. Food justice or food sovereignty? Understanding the rise of urban food movements in the USA. Agric. Hum. Values 2016, 33, 165-177. [CrossRef]

165. Alkon, A.H.M.; Mares, T.M. Food sovereignty in US food movements: Radical visions and neoliberal constraints. Agric. Hum. Values 2012, 29, 347-359. [CrossRef]

166. Alonso-Fradejas, A.; Borras, S.M.; Holmes, T.; Holt-Giménez, E.; Robbins, M.J. Food sovereignty: Convergence and contradictions, conditions and challenges. Third World Q. 2015, 36, 431-448. [CrossRef]

167. Hinrichs, C.C. The practice and politics of food system localization. J. Rural Stud. 2003, 19, 33-45. [CrossRef]

168. Fairbairn, M. Framing transformation: The counter-hegemonic potential of food sovereignty in the US context. Agric. Hum. Values 2012, 29, 217-230. [CrossRef]

169. Misra, M. Moving away from technocratic framing: Agroecology and food sovereignty as possible alternatives to alleviate rural Malnutrition in Bangladesh. Agric. Hum. Values 2018, 35, 473-487. [CrossRef]

170. Alvesson, M.; Sköldberg, K. Reflexive Methodology: New Vistas for Qualitative Research; Sage: London, UK, 2000.

171. Fischer, F. Reframing Public Policy. Discursive Politics and Deliberative Practices; Oxford University Press: Oxford, UK, 2003.

172. Bos, A.P.; Grin, J. "Doing" reflexive modernization in pig husbandry: The hard work of changing the course of a river. Sci. Technol. Hum. Values 2008, 33, 480-507. [CrossRef]

173. Bos, A.P.; Groot Koerkamp, P.W.G.; Gosselink, J.M.J.; Bokma, S.J. Reflexive interactive design and its application in a project on sustainable dairy husbandry systems. Outlook Agric. 2009, 38, 137-145. [CrossRef]

174. Weber, M.; Rohracher, H. Legitimizing research, technology and innovation policies for transformative change: Combining insights from innovation systems and multi-level perspective in a comprehensive 'failures' framework. Res. Policy 2012, 41, 1037-1047. [CrossRef]

175. Lieberman, M.; Gannt, R.; Gilbert, D.; Trope, Y. Reflexion and reflection: Social cognitive neuroscience approach to attributional influence. Advances in Experimental Social Psychology 2002, 34, 199-249.

176. Grin, J. Reflexive modernization as a governance issue: Designing and shaping re-structuration. In Reflexive Governance for Sustainable Development; Voß, J.-P., Bauknecht, D., Kemp, R., Eds.; Edward Elgar: Cheltenham, UK, 2006; pp. 54-81. 
177. Pigford, A.-A.E.; Hickey, G.M.; Klerkx, L. Beyond agricultural innovation systems? Exploring an agricultural innovation ecosystems approach for niche design and development in sustainability transitions. Agric. Syst. 2018, 164, 116-121. [CrossRef]

178. Van der Veen, M. Agricultural innovation: Invention and adoption or change and adaptation? World Archaeol. 2010, 42, 1-12. [CrossRef]

179. OECD. Agricultural Innovation Systems: A Framework for Analysing the Role of Government; The Organisation for Economic Co-operation and Development: Paris, France, 2013.

180. World Bank. Agricultural Innovation System: An Investment Sourcebook; World Bank: Washington, DC, USA, 2012. 